\title{
Non-climatic control of glacier-terminus fluctuations in the Wrangell and Chugach Mountains, Alaska, U.S.A.
}

\author{
MatThew STURM, \\ U.S.Army Cold Regions Research and Engineering Laboratory-Alaska, \\ Fort Wainwright, Alaska 99703-7860, U.S.A. \\ DoROTHY K. HALL, \\ NASA-Goddard Space Flight Center, Code 974, Greenbelt, Maryland 20771, U.S.A. \\ CARL S. BENSON, \\ Geophysical Institute, University of Alaska-Fairbanks, Fairbanks, Alaska 99775, U.S.A. \\ William O. Field \\ Formerly of the American Geographical Society, New York; now \\ Box 583, Great Barrington, Massachusetts 01230, U.S.A.
}

\begin{abstract}
Fluctuations of glacier termini were studied in two regions in Alaska. In the Wrangell Mountains, 15 glaciers on Mount Wrangell, an active volcano, have been monitored over the past 30 years by surveying, photogrammetry and satellite. Results, which are consistent between different methods of measurement, indicate that the termini of most glaciers were stationary or retreating slightly. However, the termini of the $30 \mathrm{~km}$ long Ahtna Glacier and the smaller Center and South MacKeith Glaciers began to advance in the early 1960s and have advanced steadily between 5 and $18 \mathrm{~m} \mathrm{a}^{-1}$ since then. These three glaciers flow from the active North Crater, where increased volcanic heating since 1964 has melted over $7 \times 10^{7} \mathrm{~m}^{3}$ of ice. We suspect that volcanic meltwater has changed the basal conditions for the three glaciers, resulting in their advance.

The terminus fluctuations of six tide-water and near-tide-water glaciers in College Fjord, Prince William Sound, have been monitored since 1931 by surveying, photogrammetry and, most recently, by satellite imagery. Harvard Glacier, a $40 \mathrm{~km}$ long tide-water glacier, has been advancing at an average rate of nearly $20 \mathrm{~m} \mathrm{a}^{-1}$ since 1931, while the adjacent Yale Glacier has retreated at approximately $50 \mathrm{~m} \mathrm{a}^{-1}$ during the same period though, for short periods, both of these rates have been much higher. The striking contrast between the terminus behavior of Yale and Harvard Glaciers, which parallel each other in the same fiord, and are derived from the same snowfield, supports the hypothesis that their terminus behavior is largely the result of dynamic controls rather than changes in climate.
\end{abstract}

\section{INTRODUGTION}

The advance or retreat of a glacier may be a good indicator of climate change, especially when many glaciers in a region are considered. However, several dynamic processes can result in terminus changes that are independent of climate. Best known of these is the phenomenon of surging, which has resulted in terminus advances of many kilometers in just a few years (Meier and Post, 1969). There are a number of excellent studies of surge-type glaciers including Variegated Glacier in Alaska (Kamb and others, 1985; Raymond and Harrison, 1988) and Trapridge Glacier in neighboring Yukon Territory, Canada (Clarke and others, 1984).
Several lesser known dynamic processes can result in non-climatic terminus changes. Mud and ash emitted by volcanic eruptions can blanket the ablation area of a glacier, reducing melt and triggering an advance (Muller and Coulter, 1957; Sturm and others, 1986, 1988). In a similar fashion, massive amounts of rock can fall from over-steepened slopes or be shaken down by earthquakes, covering part of a glacier in a thick mantle of debris. This debris increases the load, decreases the ablation, and can result in an advance of the glacier (Miller, 1960; Ragle and others, 1965; Shreve, 1966; Bull and Marangunic, 1967; Field, 1968; Post, 1968; Tuthill and others, 1968; Reid, 1969; Marangunic, 1972; Gardner and Hewitt, 1990). In this paper we focus on termini changes resulting 
from two other non-climatic phenomena: volcanic heating and the tide-water glacier cycle. The examples presented here from the Wrangell and Chugach Mountains of Alaska demonstrate the importance of understanding the dynamic setting when attempting to interpret changes in climate from glacier-terminus fluctuations.

The examples also demonstrate the way in which methods of monitoring glacier-terminus fluctuations have evolved during this century and how they can be combined to produce long records ( $80-100$ years) of terminus fluctuations. In 1926, one of the authors (W. O.F.) began making measurements on Alaskan tidewater glaciers. At that time, an expedition of several months' duration was required to get to the glaciers and do the mapping. Termini were surveyed using a theodolite from control points established by triangulation. Such surveys are accurate to within a few meters. By the 1940s, aerial photography of Alaskan glaciers began to be used to monitor terminus fluctuations. With proper groundcontrol points, photogrammetric techniques can be used to produce maps from which terminus changes of about $10 \mathrm{~m}$ or less can be measured. The photogrammetric measurements can be related to the older surveys if the control points can be identified on the photographs. Within the last two decades, it has become possible to measure glaciers from space (Swithinbank and others, 1988). Using digital processing, images taken from satellites can be used to measure terminus changes accurate to approximately $\pm 80 \mathrm{~m}$ without the need for control surveys. This is especially valuable in areas where terrestrial surveys are difficult or impossible. The satellite images can be related to aerial photographs by matching topographic features, and to the older terrestrial surveys by identifying topographic features near the survey points. While the advent of remote sensing has greatly reduced the time and effort necessary to make glacier-terminus measurements, highly accurate measurements still require surveying or controled aerial photography, but this may change in time.

\section{METHODS}

Specific details of the three methods used in the study are:

(1) Terrestrial surveys. Intersection surveys using a theodolite from a base line of known length, or bearingdistance surveys using a theodolite and distance ranger from a known point have been used to map glacier termini with an accuracy of $\pm 5 \mathrm{~m}$ or better, depending on how well the base line was established. Glaciers in College Fjord in the Chugach Mountains were surveyed in this manner by W. O. F. in 1931, 1935, 1961, 1964, 1966, 1974 and 1976. A survey in 1957 was done by M. T. Millett. The most recent survey was done in 1989 by M.S. and C. S. B. Earlier surveys in College Fjord were done in 1899 (Gilbert, 1903), 1905, 1909 (Grant and Higgins, 1913) and 1910 (Tarr and Martin, 1914). Glaciers on the northeast flank of Mount Wrangell were surveyed annually from 1977 to 1983 by the authors.

(2) Photogrammetry. Changes in the terminus positions of glaciers were determined by comparing aerial and terrestrial photographs. On Mount Wrangell, the first aerial photographs were taken by Bradford Washburn in 1937. Subsequent aerial photography was done by the USGS in 1948 and 1957. We have taken oblique and vertical aerial photographs of the summit and flank glaciers from 1961 to the present. Orthophoto maps* (scale $=1: 25000)$ were made from the photographs taken in 1957, 1977, 1979, 1981 and 1988 (Sturm, 1983; Benson and Follett, 1986). Comparison of these orthophoto maps allows changes in glacier termini to be measured to $\pm 10 \mathrm{~m}$. In College Fjord, terrestrial photographs are available from 1899 (Gilbert, 1903), 1909 (Grant and Higgins, 1913), 1910 (Tarr and Martin, 1914) and 1914 (Keen, 1915). We (primarily American Geographical Society parties with W.O.F.) have continued the series with photographs taken from the same vantage points during the survey years mentioned above. Austin Post supplied data from vertical aerial photographs taken of Yale Glacier in 1987 and 1990.

(3) Satellite imagery. Landsat Multispectral Scanner (MSS; $80 \mathrm{~m}$ resolution) and Thematic Mapper (TM; $30 \mathrm{~m}$ resolution) images were analyzed to determine terminus changes (Krimmel and Meier, 1975; Hall and others, 1988). Lower-resolution MSS images were registered digitally to the higher-resolution TM images using rock outcrops as control points. Fifteen or more control points were matched in each 512 by 512 pixel image to ensure good registration. Once registered, changes in terminus positions could be determined for all the glaciers in the image with a resolution of about $80 \mathrm{~m}$. The images we have used are:

Mount Wrangell:

MSS (18 September 1973) vs TM (16 September 1986), College Fjord:

MSS (15 August 1973) vs TM (1 August 1985).

Terminus changes measured from satellite images were consistent with positions determined by photogrammetry or surveying.

\section{TERMINUS ADVANCE IN THE WRANGELL MOUNTAINS ASSOGIATED WITH VOLGANIC HEATING}

Mount Wrangell (elevation $4317 \mathrm{~m}$ ) is an active volcano located near the northwestern end of the Wrangell Mountains (Fig. 1, inset) (Benson, 1968). Its summit caldera is about $6 \mathrm{~km}$ across and filled with ice to depths greater than $500 \mathrm{~m}$ (Clarke and others, 1989); along its rim are three craters, $0.5-1.0 \mathrm{~km}$ in diameter, and several active fumarole fields. Fifteen glaciers radiate from the

"Orthophoto maps are composites made from stereo pairs of vertical photographs that have been corrected for the perspective distortion that occurs naturally in aerial photographs. The result is a photographic map that is an orthographic projection on which the scale is constant at all points. 


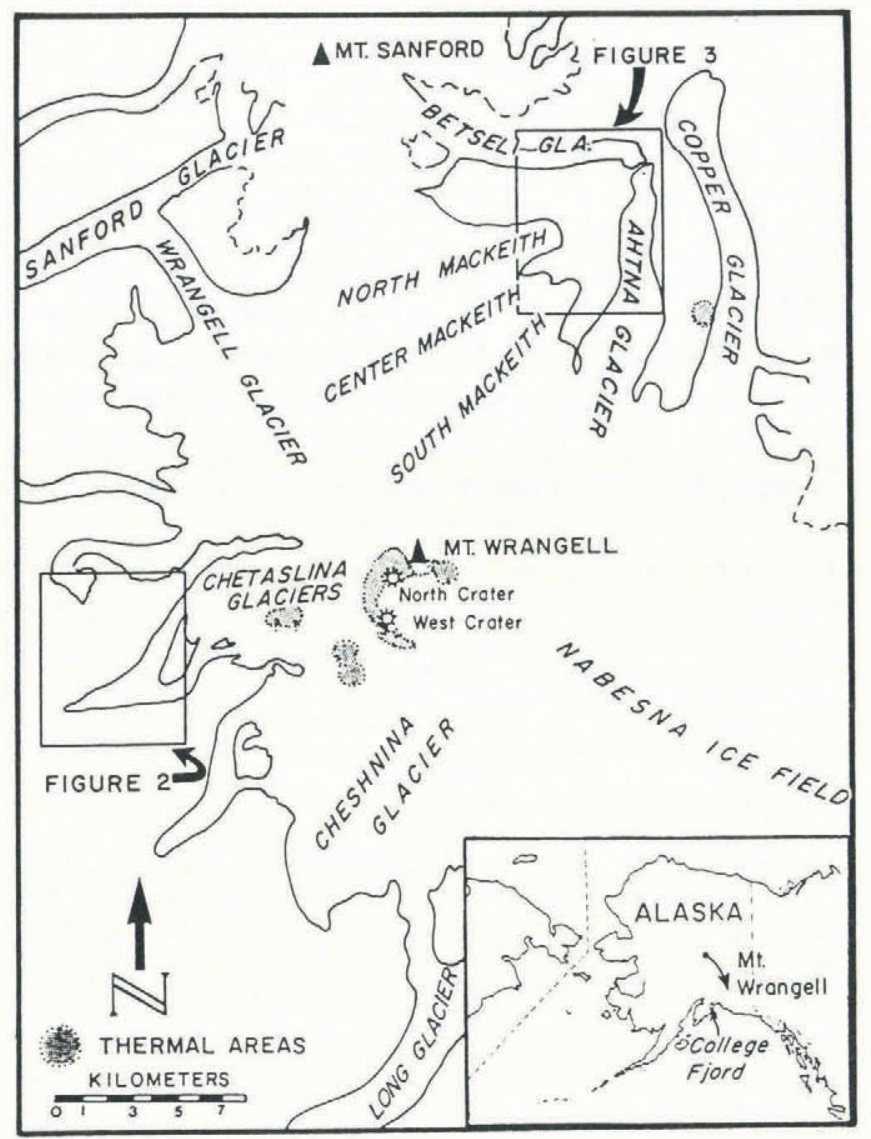

Fig. 1. Mount Wrangell in the Wrangell Mountains of Alaska, showing the 15 glaciers that radiate from its summit. The inset shows the location of Mount Wrangell and College Fjord in the Chugach Mountains.

summit ice cap (Fig. 1). Mount Wrangell's recent volcanic history includes probable minor phreatic eruptions in 1899, 1902, 1908, 1911, 1912, 1921 and 1930 (Motyka, 1983). No lava flows younger than several thousand years have been identified nor are they likely to exist (personal communication from C.J. Nye, Alaska Division of Geological and Geophysical Surveys, 1990).

An abrupt increase in the volcanic heat flux centered under the North Crater (Fig. 1) took place in 1965 (Benson and others, 1975; Benson and Motyka, 1978; Motyka, 1983; Benson and others, 1985). We believe this was a result of the great Alaska earthquake of 27 March 1964 centered in nearby Prince William Sound (National Academy of Sciences, 1968). The change in heat flux was manifest in increased fumarolic activity along the rim and increased melting of the ice in the North Crater. Between 1908 (Dunn, 1909) and 1965 this ice-filled crater was in equilibrium, with accumulation balanced by glacier flow and basal melting due to geothermal heat (there is no surface melting at this elevation). Since 1965 , more than $7 \times 10^{7} \mathrm{~m}^{3}$ has melted in the crater (Benson and Motyka, 1978; Motyka, 1983, Benson and others, 1985; Benson and Follett, 1986). Some of the meltwater percolated into the hot rocks of the crater floor and increased the local heat flux by forming hydrothermal convection cells; some was lost to the atmosphere as steam (Motyka, 1983), and some ran off as subglacier flow at the rock/ice interface. When melting exceeded the removal processes, a lake would form in the crater, such as happened in 1974, 1979, 1981 and 1983.

The increased heating was strongly focused under the North Crater and on the northeast flank of the volcano near the crater. Changes in ice-surface contours measured in 1961, 1965 and 1975 (Bingham, 1967; Benson, 1968; Motyka, 1983) show that the snow-surface elevation in the summit caldera did not change $( \pm 1 \mathrm{~m})$. The same measurements indicate that heating extended about $0.5 \mathrm{~km}$ from the North Crater rim on its northeast side. Due to the local topography, most of the subglacial meltwater produced by volcanic heating outside the crater probably drained down the northeast flank of the mountain.

Between the end of the 19th century and 1957 when aerial mapping photographs were taken, there was a general retreat of all the glaciers on Mount Wrangell. Comparison of the USGS maps made from the 1957 photographs with plane-table maps made in 1902 (Mendenhall, 1905) show that most of the glaciers retreated between 100 and $400 \mathrm{~m}$ (e.g. see Fig. 2). The MacKeith Glaciers on the northeast flank of the volcano were unusual because they retreated 3-5 times further during the same period (Fig. 3). When first observed in 1902 (Mendenhall, 1905), they were confluent with Ahtna Glacier, which was connected to Betseli Glacier. The deglaciated area is now covered by thin, discontinuous ice-cored moraine with kettle lakes, sparse vegetation and lichen cover consistent with recent deglaciation (Sturm, 1983). (MacKeith, Ahtna and Betseli are unofficial

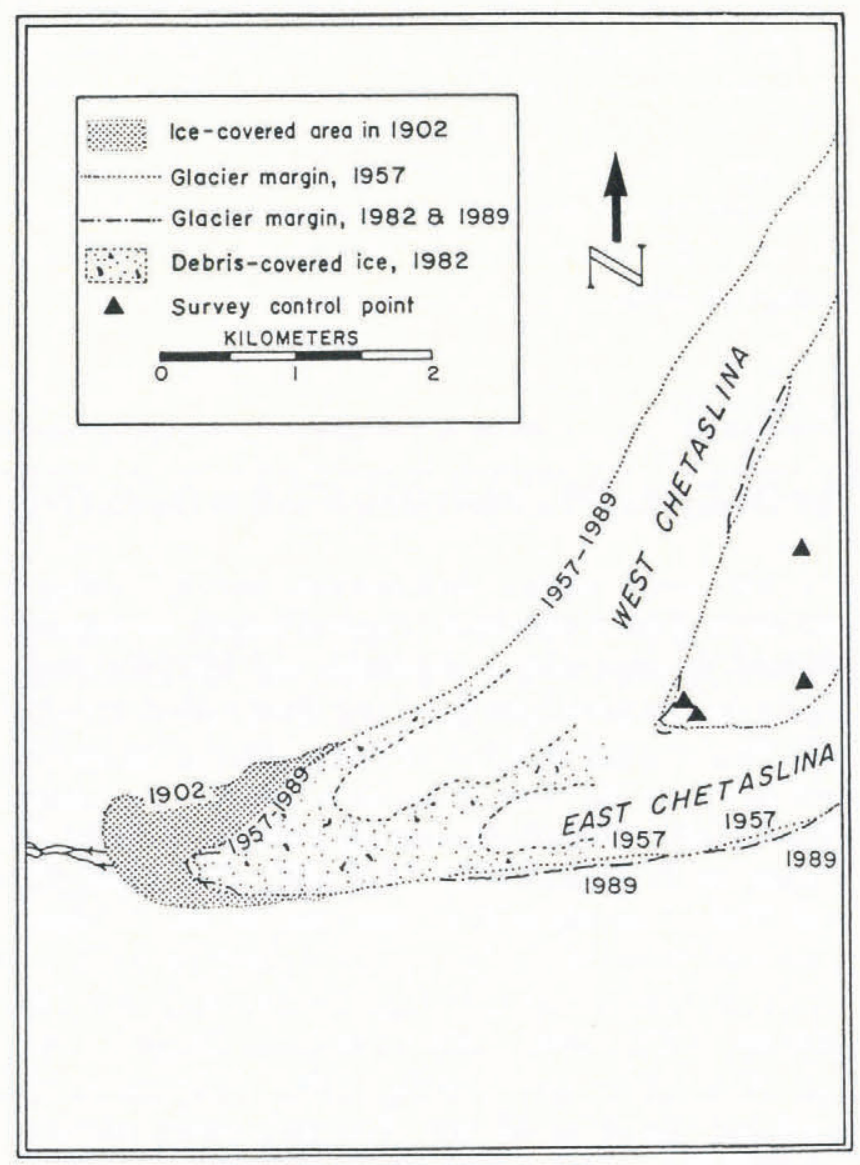

Fig. 2. The terminus of Chetaslina Glacier, Mount Wrangell, 1902-89. Little or no change in the terminus occurred between 1957 and 1989. 


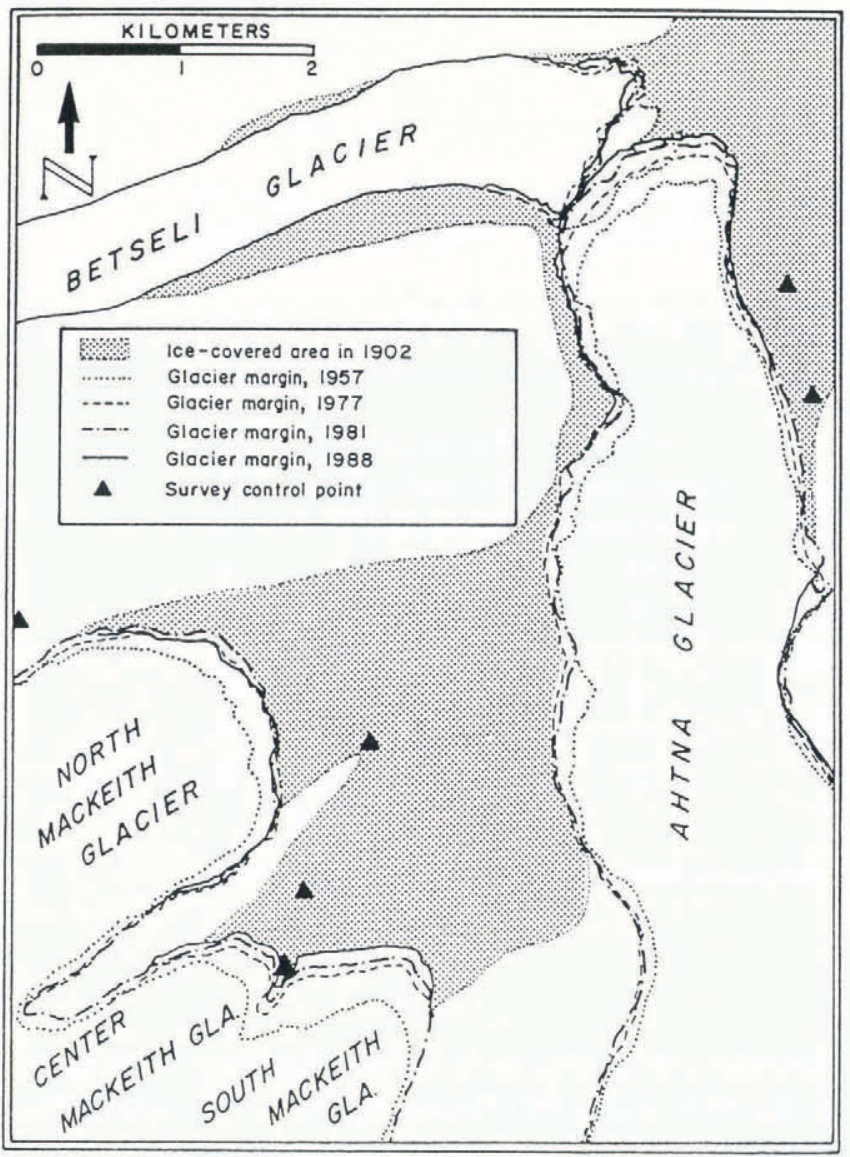

Fig. 3. Terminus position of the glaciers on the northeast flank of Mount Wrangell, 1902-88. The glaciers were in essentially the same positions in 1957 and 1964.

names.) The reliability of the 1902 maps has been checked by comparing topographic features depicted on the map with the same features shown on the 1957 USGS maps prepared from aerial photographs. There is good agreement between maps, suggesting that 1902 terminus positions are reliable to $\pm 250 \mathrm{~m}$.
The hypsometric characteristics (distribution of area with altitude) of the MacKeith Glaciers are also unusual (Fig. 4). Because they are unconfined by valley walls, they have hypsometric curves that are similar to those of a piedmont-lobe glacier (Ahlmann, 1948). Their areal maximum occurs at an altitude that is slightly higher than the equilibrium-line altitude (ELA). Consequently, they are likely to be sensitive to small shifts in the ELA resulting from climate change. The other glaciers on Mount Wrangell, including Ahtna Glacier on the northeast flank (Fig. 3), and the Chetaslina Glaciers on the west flank (Fig. 2), have hypsometric curves (Fig. 4) which are similar to those of typical valley glaciers (Ahlmann, 1948).

About 1965, the South, Center and North MacKeith Glaciers, and the $30 \mathrm{~km}$ long Ahtna Glacier (Figs 1 and 3) began to advance and have continued to do so for the past 25 years. While these glaciers, which are adjacent to one another and flow directly from the active North Crater, have been advancing, all other glaciers on Mount Wrangell and on nearby Mount Sanford ( $4950 \mathrm{~m}$ ) have remained stationary or continued to retreat. Photographs show that MacKeith and Ahtna Glaciers had retreated to their minimum positions by the 1940s. They were nearly stationary from the 1940 s to the 1960 s, then in $1965( \pm 2$ years) they began to advance. North MacKeith Glacier, which flows from an accumulation area that is only partly on Mount Wrangell, with about half its accumulation coming from nearby Mount Sanford (Sturm, 1983) advanced about $300 \mathrm{~m}$ between 1957 and 1981, but has been stationary since that time. The other three glaciers on the northeast flank have advanced $320-480 \mathrm{~m}$ in the past 25 years. Average rates of advance measured by comparing orthophoto maps, terrestrial surveying and comparison of satellite images are given in Table 1. The start of these advances coincided with the abrupt increase in volcanic heating of the North Crater.

In summary, in 1902 the glaciers on the northeast flank of Mount Wrangell were 1-2 km advanced from their present positions. The ice was probably quite thin and debris-laden. Between 1902 and the 1940s the

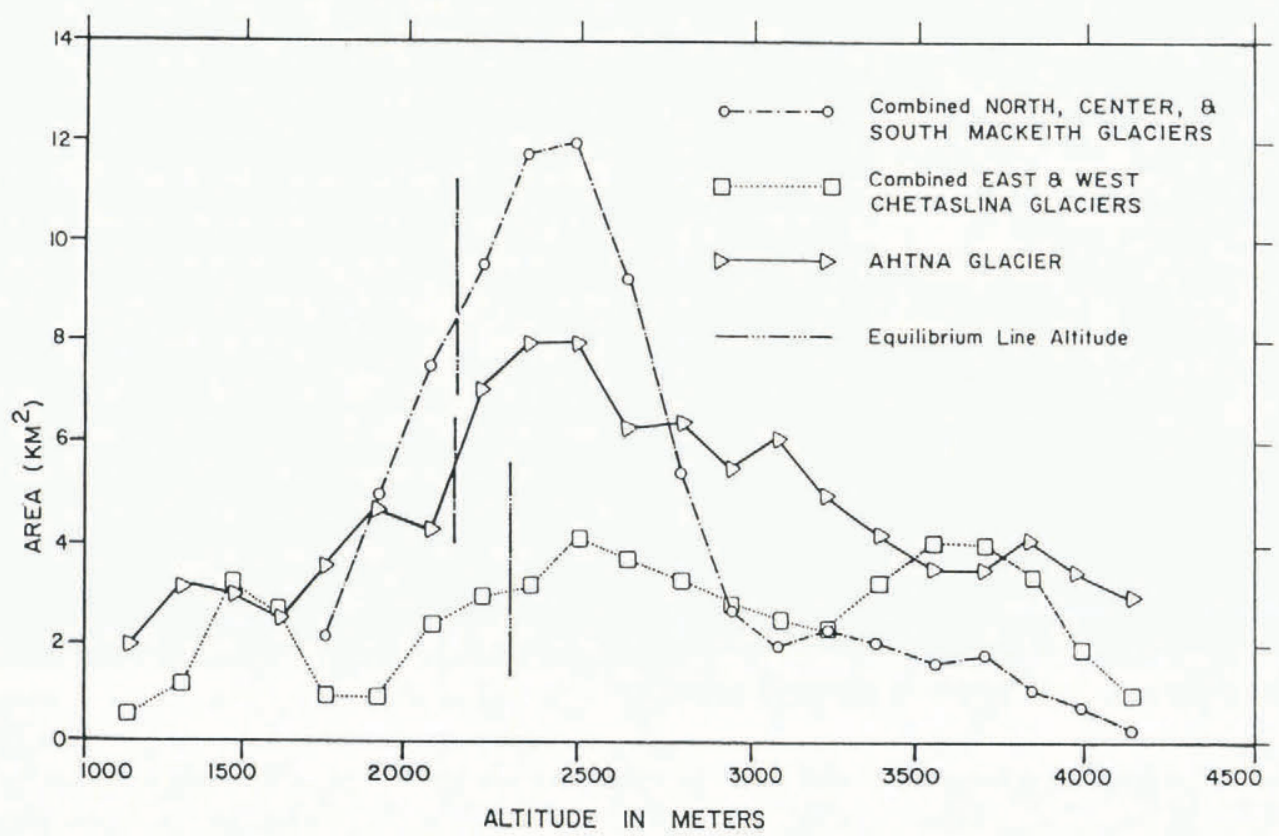

Fig. 4. Hypsometric curves (area-altitude) for glaciers on Mount Wrangell. 
Table 1. Advance and retreat rates of glaciers on Mount Wrangell

\begin{tabular}{|c|c|c|c|c|c|c|}
\hline Time interval & $\begin{array}{l}\text { Ahtna } \\
\text { Glacier }\end{array}$ & $\begin{array}{l}\text { S. MacKeith } \\
\text { Glacier }\end{array}$ & $\begin{array}{l}\text { C. MacKeith } \\
\text { Glacier }\end{array}$ & $\begin{array}{c}\text { N. MacKeith } \\
\text { Glacier }\end{array}$ & $\begin{array}{l}\text { Betseli } \\
\text { Glacier }\end{array}$ & $\begin{array}{c}\text { Chetaslina } \\
\text { Glacier }\end{array}$ \\
\hline & $\mathrm{ma}^{-1}$ & $\mathrm{ma}^{-1}$ & $\mathrm{ma}^{-1}$ & $\mathrm{ma}^{-1}$ & $\mathrm{ma}^{-1}$ & $\mathrm{ma}^{-1}$ \\
\hline $1902-37$ & Retreating & -50 & -86 & -73 & Retreating & -11 \\
\hline $1937-57$ & Stationary? & Stationary? & Stationary? & Stationary? & Retreating? & -11 \\
\hline $1957-64$ & Stationary? & Stationary? & Stationary? & Stationary? & Retreating? & 0 \\
\hline $1964-77$ & 10 & 18 & 16 & 10 & -16 & 0 \\
\hline $1978-79$ & 15 & Advancing? & Advancing? & 6 & 0 & 0 \\
\hline $1979-80$ & 0 & 5 & Advancing? & 6 & 0 & 0 \\
\hline $1980-81$ & -8 & 6 & 6 & 6 & 0 & 0 \\
\hline $1981-82$ & 0 & 8 & Advancing? & ? & 0 & 0 \\
\hline $1982-88$ & 10 & 17 & 14 & -6 & 0 & 0 \\
\hline
\end{tabular}

Minus sign indicates retreat rate.

MacKeith Glaciers retreated, leaving behind a thin, icecored moraine. Other glaciers on the mountain retreated during the same period, but a much smaller distance. About 1965, the glaciers which flow from the vicinity of the North Crater began to advance and have continued to do so to the present day. No other glaciers in the Wrangell Mountains have shown similar behavior. The start of these advances coincided with an abrupt increase in volcanic heating of the North Crater.

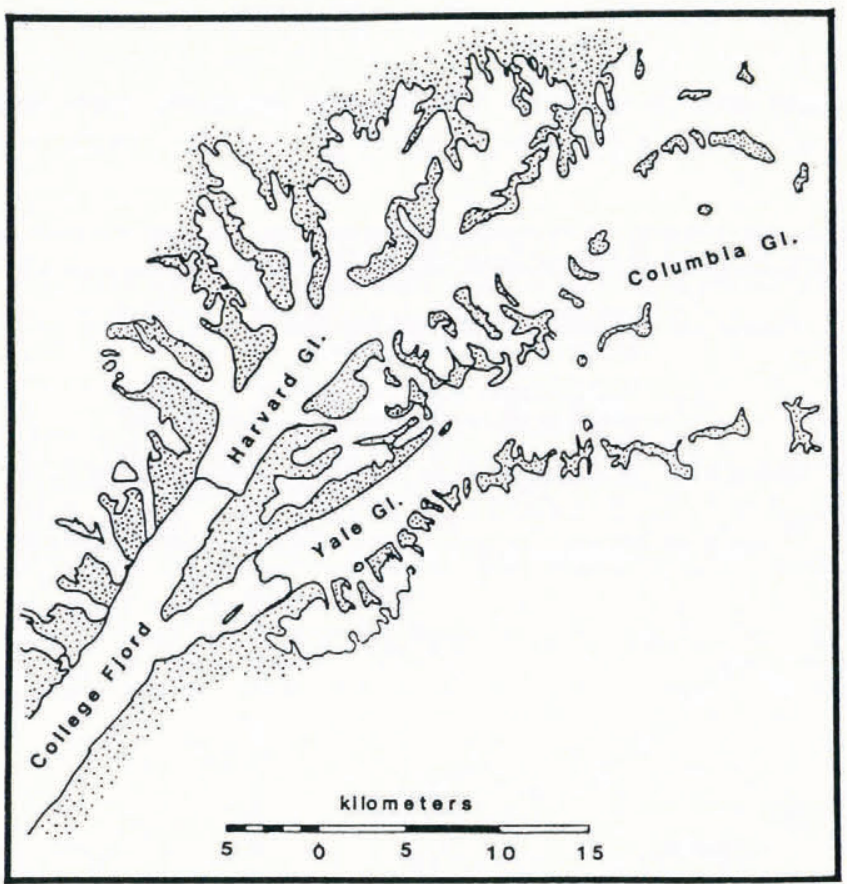

Fig. 5. The joint accumulation basin of Harvard, Yale and Columbia Glaciers in the Chugach Mountains. Surface slope of Harvard Glacier is $3^{\circ}$; surface slope of Yale Glacier is $5^{\circ}$. College Point is the tip of land between Harvard and Yale Glaciers.

\section{TERMINUS ADVANCE AND RETREAT DUE TO TIDE-WATER INTERACTIONS IN GOLLEGE FJORD}

College Fjord, a $40 \mathrm{~km}$ long fiord in the northwest part of Prince William Sound, cuts into the heart of the Chugach Mountains (inset, Fig. 1) and contains five tide-water glaciers, five large valley glaciers and dozens of smaller glaciers (Fig. 5). The glaciers of College Fjord have been described by Gilbert (1903), Tarr and Martin (1914) and Field (1932a, b). A summary of all historical references to glaciers in College Fjord and an extensive discussion of their terminus behavior was prepared by Field (1975). The two largest tide-water glaciers in the fiord are Harvard and Yale Glaciers. They are derived from the same snowfields, which connect with the snowfields of Columbia Glacier (Fig. 5). Four other glaciers in the fiord (Wellesley, Vassar, Bryn Mawr and Smith Glaciers) descend the west wall of the fiord to the sea. Observations show that Harvard Glacier has advanced, while there has been a simultaneous retreat of Yale Glacier, with the retreat rate more than twice the advance rate.

Harvard Glacier has been advancing since 1905, and possibly earlier (Fig. 6). It was seen from a distance of about $20 \mathrm{~km}$ and mapped by Whidbey in 1794 and by Applegate in 1887 (Tarr and Martin, 1914; Field, 1975). Members of the Harriman expedition, who were able to get closer, photographed and described the glacier in detail (Gilbert, 1903), but the first reliable maps were prepared by Grant and Higgins (1913) in 1905 and 1909. It was mapped again in 1910 (Tarr and Martin, 1914) and 1914 (Keen, 1915). This record has been extended by surveys which were begun by one of the authors (W.O.F.) in 1931 and continued every few years to the present. Comparison of maps and descriptions suggests that the terminus was nearly stationary between 1887 and 1905. In 1905 , it began to advance. In 1935, it was still advancing and knocking over 250 year-old trees (Cooper, 1942; 


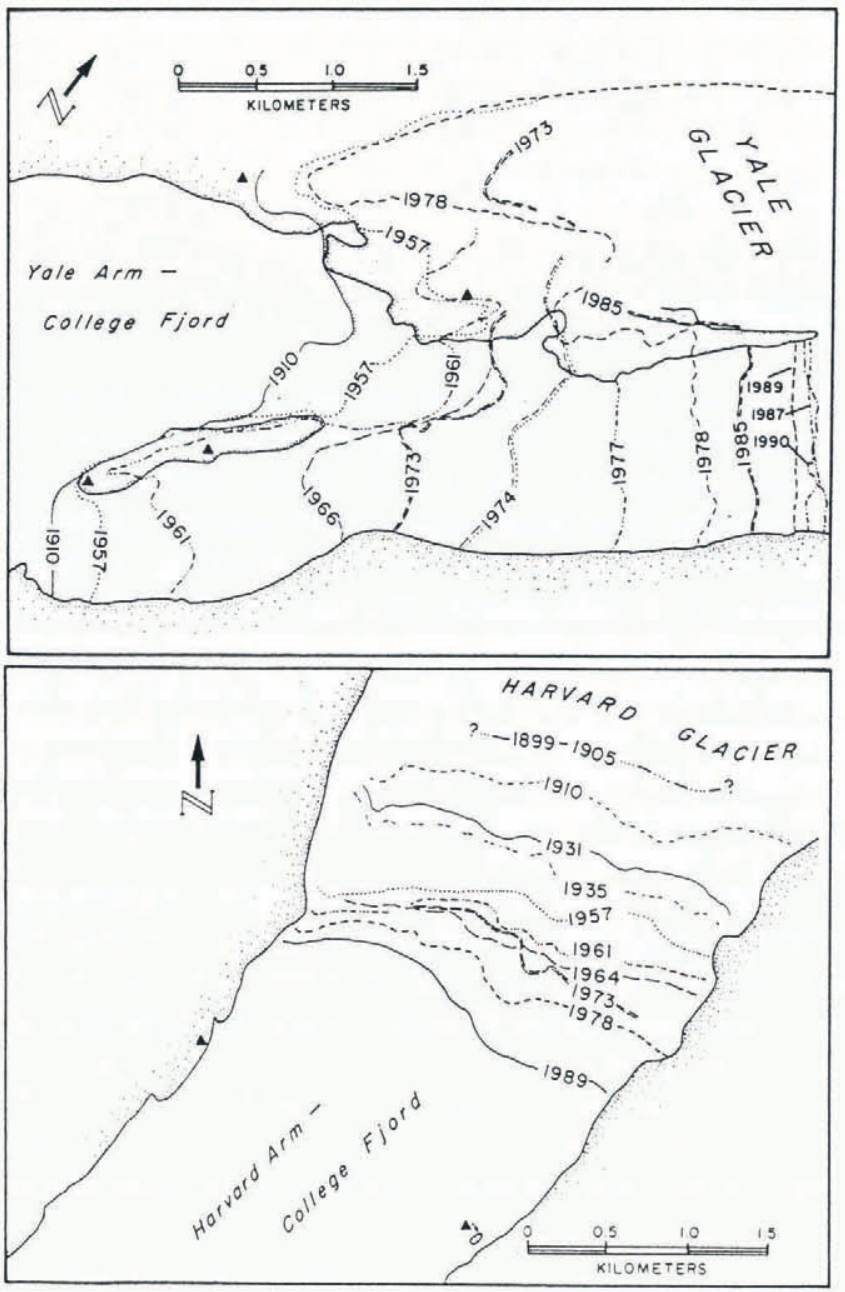

Fig. 6. Terminus positions of Yale and Harvard Glaciers, Prince William Sound, College Fjord, Alaska. Position for 1973 (Harvard Glacier) and 1973 and 1985 ( Yale Glacier) are from satellite images. 1987 and 1990 positions for Yale Glacier are from data supplied by A. Post.

Viereck, 1968), indicating that it had not been that far advanced since at least 1685 . The advance was continuing when the glacier was surveyed in July 1989. Between 1905 and 1969 , it advanced at an average rate of $12-20 \mathrm{~m} \mathrm{a}^{-1}$ (Field, 1975; Brown and others, 1982; Meier and Post, 1987); since 1969, its rate has averaged $18-30 \mathrm{~m} \mathrm{a}^{-1}$ (Table 2).

Yale Glacier has been retreating since the early 19th century (Fig. 6). In 1794, when College Fjord was first visited, Whidbey of Vancouver's expedition was unable to proceed more than $5 \mathrm{~km}$ up the fiord due to floating ice. In 1887, Applegate got about the same distance (near the present-day Coghill Point) (Tarr and Martin, 1914; Field, 1975). From these observations, it is reasonable to conclude that rapid calving was taking place from a large tide-water glacier, probably Yale Glacier. Botanical evidence (Cooper, 1942; Viereck, unpublished) suggests that Yale Glacier reached its maximum advance sometime between Whidbey's and Applegate's visits. At that time, the terminus was located near the entrance of Yale Arm at College Point (Fig. 5). By 1910, when Tarr and Martin (1914) mapped its terminus, Yale Glacier had retreated between 3.5 and $5 \mathrm{~km}$. The thick alder growth in front of
Table 2. Advance rates of Harvard Glacier

$\begin{array}{cc}\text { Time interval Distance } & \text { Advance rate } \\ \mathrm{m} & \mathrm{m} \mathrm{a}^{-1}\end{array}$

$\begin{array}{crr}\text { West side of glacier } & & \\ 1899-1905 & 0 & 0 \\ 1905-10 & 270 & 54 \\ 1910-31 & 300 & 14 \\ 1931-35 & 100 & 25 \\ 1935-57 & 490 & 22 \\ 1957-61 & 170 & 43 \\ 1961-64 & -40 & -13 \\ 1964-76 & 80 & 7 \\ 1976-78 & 0 & 0 \\ 1978-89 & 150 & 14\end{array}$

Total distance $1520 \mathrm{~m}$

Average rate

East side of glacier

1899-1905

1905-10

0

0

1910-31

370

74

1931-35

240

11

1935-57

160

130

320

40

$1957-61$

140

250

1964-76

1976-78

1978-89

446

6

80

47

21

0

41

Total distance

$2056 \mathrm{~m}$

Average rate

23

Average advance rate, 1899-1989

20

*Advance rates do not include satellite positions from 1973 and 1985.

the glacier suggested that most of the retreat had occurred before 1860. Between 1910 and 1957, Yale Glacier had a complex history (Field, 1975) with a net retreat of $0.5 \mathrm{~km}$.

In 1957, the glacier began a rapid retreat which continued unabated until about 1987. Retreat rates during this period were highly variable (Table 3 ). In July 1989, the terminus of Yale Glacier had retreated so far that it could not be surveyed from the existing control points. Therefore, the most recent terminus positions of Yale Glacier shown in Figure 6 are based (a) on satellite imagery for 1985, (b) on observations and terrestrial photographs taken in 1989, and (c) data from vertical aerial photographs taken in 1987 and 1990 supplied by A. Post (personal communication, 1991). By 1974, Yale Glacier had retreated into a reach of the fiord which was only half as wide as the reach it occupied prior to 1974; 
Table 3. Retreat rates of Yale Glacier

Time interval Distance

$\mathrm{m}$

$\mathrm{m} \mathrm{a}^{-1}$

$\begin{array}{crc}\text { South side of glacier } & & \\ 1910-57 & 320 & 7 \\ 1957-61 & 480 & 120 \\ 1961-66 & 1020 & 204 \\ 1966-74 & 960 & 120 \\ 1974-78 & 1380 & 345 \\ 1978-85 & 260 & 37 \\ 1985-87 & 320 & 160 \\ 1987-90 & 120 & 40 \\ & & \text { Average rate } \\ \text { Total distance } & & 61 \\ 4860 \mathrm{~m} & & \\ & & 11 \\ \text { North side of glacier } & 500 & 140 \\ 1910-57 & 560 & 32 \\ 1957-61 & 160 & 58 \\ 1961-66 & 460 & 230 \\ 1966-74 & 920 & 40 \\ 1974-78 & 280 & 220 \\ 1978-85 & 440 & 0 \\ 1985-87 & 0 & \\ 1987-90 & & \text { Average rate } \\ & & 42 \\ \text { Total distance } & & 52 \\ \text { 3320 m } & & \\ & & \end{array}$

*Retreat rates do not include satellite positions from 1973 and 1985.

according to Mercer (1961), this should have caused a decrease in the retreat rate. Instead, its retreat rate accelerated, reaching a maximum value of $345 \mathrm{~m} \mathrm{a}^{-1}$ between 1974 to 1978 (Table 3). This was apparently due to the greater water depth in this reach of the fiord (personal communication from A. Post), which caused a higher rate of calving. We think it is unlikely that Yale Glacier will continue to retreat much longer. The active calving terminus is only a few hundred meters downglacier from a distinct rise in the glacier surface, indicating a step in the subglacial topography. The glacier has probably reached its stable retracted position.

The smaller glaciers in College Fjord (Wellesley, Vassar, Bryn Mawr and Smith Glaciers) reached their maximum positions at the end of the 19th century, as did Yale Glacier (Field, 1975). Since that time, they have undergone modest retreat punctuated by small advances. Around 1910, all four glaciers experienced a small advance. In the mid-1930s, Bryn Mawr and Wellesley Glaciers experienced another small advance; these same two glaciers, along with Smith Glacier, experienced a third advance in the late 1960s. Our most recent observations suggest that Bryn Mawr Glacier has advanced since last observed in 1976, while the others have shown little change.

\section{DISCUSSION}

The advance of the glaciers on the northeast flank of Mount Wrangell does not appear to be the result of climate change. We suspect that volcanic meltwater has changed the basal conditions of these glaciers, changing their flow dynamics and thereby resulting in their advance. It is only glaciers flowing from the northeast side of the North Crater that are advancing, and they began to advance in 1965 when volcanic activity and the abundance of meltwater in the North Crater increased. Changes in ice-surface contours indicate that most run-off from subglacial melting outside the crater would flow down the northeast flank.

There is other supporting evidence: volcanically produced subglacial run-off is not subject to seasonal variation, as is surface run-off; therefore we would expect to see little seasonal variation in the flow characteristics of the glaciers which are advancing, and that is indeed the case. The glaciers on the northeast flank of Mount Wrangell show little or no seasonal variation in surface speed. In contrast, Chetaslina Glacier on the west side of Mount Wrangell shows more than a $50 \%$ increase in surface speed during the spring and summer (Sturm, 1983). Chetaslina Glacier is closer to the "normal" mode of glacier flow, showing an increase in speed in spring and summer when surface run-off penetrates to the bed of the glacier and increases sliding (Sturm, 1983; Echelmeyer and Harrison, 1990).

It is true that the MacKeith Glaciers have the type of hypsometry which makes them sensitive to changes in climate (Fig. 4). Their configuration favors a more pronounced terminus retreat if the altitude of the equilibrium line shifts upward, and a greater advance if it shifts down than would be observed for a normal valley glacier. We speculate that this is why the MacKeith Glaciers retreated 2-4 times farther than the other glaciers on Mount Wrangell during the climatically induced general retreat between 1902 and the 1940s. However, the hypsometry cannot explain the recent advance of glaciers on the northeast flank of Mount Wrangell. Ahtna Glacier, which has a "normal" hypsometry that is similar to that of Chetaslina Glacier (Fig. 4) is advancing, while Chetaslina Glacier is not. Our conclusion is that the recent volcanic activity on Mount Wrangell is the cause of the advance of all the glaciers on the northeast flank of the volcano.

The striking contrast between the terminus behavior of Yale and Harvard Glaciers, which parallel each other in the same fiord and are derived from the same snowfield (Fig. 5), supports the hypothesis that their terminus behavior is largely the result of dynamic rather than climatic controls. If climate was controling the terminus behavior, we would expect more synchronous behavior between the two glaciers. With a shared accumulation area, their mass balance must be roughly the same. Their 
lengths are comparable, hence their response times to changes in mass balance should be roughly equal. Yet their terminus behavior has been distinctly opposite for greater than 100 years, suggesting dynamic control.

In general, the terminus positions of tide-water glaciers are thought to be the result of a complex interaction of fiord depth, ice thickness and calving rate, with climate and mass balance playing a secondary role. Recognition of a distinct cycle of dynamically controled advance and retreat of tide-water glaciers began with the work of Hoppe (1959) and was developed by Post (1975) and Meier and Post (1987). The tide-water glacier cycle consists of three phases:

(1) A period of slow advance (advancing 20-40 $\mathrm{m} \mathrm{a}^{-1}$ ) during which the glacier moves down the fiord through deep water by maintaining a submarine moraine shoal in front of the terminus. This shoal, which is moved in front of the glacier by continuous erosion on the proximal side and deposition on the distal side, greatly reduces iceberg calving, thereby maintaining the glacier in a positive mass balance.

(2) A period of relative stability during which the terminus is nearly stationary, terminating in shallow water on a submarine moraine. Again, calving is reduced, and calving, ablation and accumulation are in approximate balance.

(3) A period of rapid "catastrophic" retreat (100$2000 \mathrm{~m} \mathrm{a}^{-1}$ ), during which the terminus retreats off its submarine moraine shoal into deep water. This produces calving at a high rate which causes the terminus to retreat up the fiord. The high rate of calving overwhelms the ability of the glacier to supply ice to the terminus, and the retreat continues until the glacier stabilizes on another submarine shoal or becomes grounded at the head of the fiord, where it can begin building another terminal moraine.

Though the cycle listed above may be triggered by climatic change, at any given time the terminus position of the glacier is primarily controled by the balance between glacier flow and calving activity and the phase of cycle. Yale Glacier appears to be near the completion of the catastrophic retreat phase; Harvard Glacier is in the advancing phase.

\section{CONGLUSIONS}

Though the advance and retreat of glaciers can be good indicators of climate, non-climatically induced changes, such as surging and the examples presented here, are often larger than those produced by climate. It is important to understand and consider these phenomena when interpreting glacier behavior as a climatic indicator.

\section{ACKNOWLEDGEMENTS}

Hundreds of people have been involved in collecting the more than 50 years of field data we have presented here and we thank them all. In the most recent surveys and in preparing this paper we had help from C.F. Benson, the late P. MacKeith, R. Motyka, D. Solie, B. Sturm and C. Tobin. A. Post generously supplied data showing the 1987 and 1990 positions of Yale Glacier and suggested the reason for its increased retreat rate in 1974 . We also thank W. M. Kovalick for processing the Landsat data.

\section{REFERENCES}

Ahlmann, H.W. 1948. Glaciological research on the North Atlantic coasts. London, Royal Geographical Society. (Royal Geographical Society Research Series 1.)

Benson, C.S. 1968. Glaciological studies on Mount Wrangell, Alaska, 1961. Arctic, 21(3), 127-152.

Benson, C.S. and A.B. Follett. 1986. Application of photogrammetry to the study of volcano-glacier interactions on Mt. Wrangell, Alaska. Photogramm. Eng. Remote Sensing, 52(6), 813-827.

Benson, C.S. and R. Motyka. 1978. Glacier-volcano interactions of Mt. Wrangell, Alaska. University of Alaska. Geophysical Institute. Annual Report 1977-1978, 1-25.

Benson, C. S., D. K. Bingham and G. B. Wharton. 1975. Glaciological and volcanological studies at the summit of Mt. Wrangell, Alaska. International Association of Hydrological Sciences Publication 104 (General Assembly of Moscow 1971 - Snow and Ice), 95-98.

Benson, C. S., R. Motyka, D. Bingham, G. Wharton, P. MacKeith and M. Sturm. 1985. Glaciological and volcanological studies on Mt. Wrangell, Alaska. In Kotlyakov, V. M., V.N. Vinogradov and A. F. Glazovskiy, eds. Interaction between volcanism and glaciology. Academy of Sciences of the USSR. Soviet Geophysical Committee, 114-133. (Glaciological Researches 27.)

Bingham, D. 1967. Ice motion and heat flow studies on Mt. Wrangell, Alaska, 1961. (M.S. thesis, University of Alaska, Fairbanks.)

Brown, C.S., M.F. Meier and A. Post. 1982. Calving speed of Alaska tidewater glaciers, with application to Columbia Glacier. U.S. Geol. Surv. Prof. Pap. 1258-C.

Bull, C. and C. Marangunic. 1967. The earthquakeinduced slide on the Sherman Glacier, south-central Alaska, and its glaciological effects. In Ōura, H., ed. Physics of snow and ice. International Conference on Low Temperature Science ... 1966 ... Proceedings. Vol. 1. Part 1. Sapporo, Hokkaido University. Institute of Low Temperature Science, 395-408.

Clarke, G. K. C., S. G. Collins and D. E. Thompson. 1984. Flow, thermal structure and subglacial conditions of a surge-type glacier. Can. J. Earth Sci., 21(2), 232-240.

Clarke, G. K. C., G. M. Cross and C.S. Benson. 1989. Radar imaging of glaciovolcanic stratigraphy, Mount Wrangell caldera, Alaska: interpretation model and results. 7. Geophys. Res., 94(B6), 7237-7249.

Cooper, W.S. 1942. Vegetation of the Prince William Sound region, Alaska, with a brief excursion into postPleistocene climatic history. Ecol. Monogr., 12, 1-22.

Dunn, R. 1909. Conquering our greatest volcano. Harper's Monthly Magazine, 118(706), 497-509.

Echelmeyer, K. and W. D. Harrison. 1990. Jakobshavns Isbræ, West Greenland: seasonal variations in velocity - or lack thereof. 7 . Glaciol., 36(122), 82-88. 
Field, W. O., Jr. 1932a. The glaciers of the northern part of Prince William Sound, Alaska. Geogr. Rev., 22(3), 361-388.

Field, W. O., Jr. 1932b. The mountains and glaciers of Prince William Sound, Alaska. Amer. Alp. F., 1(4), 445458.

Field, W. O. 1968. The effect of previous earthquakes on glaciers. In National Research Council. Division of Earth Sciences. Committee on the Alaska Earthquake. The great Alaska earthquake of 1964. Hydrology. Part A. Washington, DC, National Academy of Sciences, 252265. (Publication 1603.)

Field, W.O., ed. 1975. Mountain glaciers of the Northern Hemisphere. Vol. 2. Hanover, NH, U.S. Army Cold Regions Research and Engineering Laboratory.

Gardner, J. S. and K. Hewitt. 1990. A surge of Bualtar Glacier, Karakoram Range, Pakistan: a possible landslide trigger. 7. Glaciol., 36(123), 159-162.

Gilbert, G. K. 1903. Alaska. Glaciers and glaciation. New York, Doubleday, Page and Company. (Harriman Alaska Expedition, Volume III.)

Grant, U.S. and D.F. Higgins. 1913. Coastal glaciers of Prince William Sound and Kenai Peninsula, Alaska. U.S. Geol. Surv. Bull., 526.

Hall, D. K., K.J. Bayr and W. M. Kovalick. 1988. Determination of glacier mass balance change using thematic mapper data. Proc. East. Snow Conf. 45th Annual Meeting, 192-196.

Hoppe, G. 1959. Glacial morphology and inland ice recession in northern Sweden. Geogr. Ann., 41(4), 193 212.

Kamb, B. and 7 others. 1985. Glacier surge mechanism: 1982-1983 surge of Variegated Glacier, Alaska. Science, 227(4686), 469-479.

Keen, D. 1915. Exploring the Harvard Glacier. Harper's Monthly Magazine, 132, 113-125.

Krimmel, R. M. and M. F. Meier. 1975. Glacier applications of ERTS images. F. Glaciol., 15(73), 391-402.

Marangunic, C. 1972. Effects of a landslide on Sherman Glacier, Alaska. Ohio State Univ. Inst. Polar Stud. Rep. 11.

Meier, M. F. and A. Post. 1969. What are glacier surges? Can. J. Earth Sci., 6(4), 807-817.

Meier, M. F. and A. Post. 1987. Fast tidewater glaciers. $\mathcal{J}$. Geophys. Res., 92(B9), 9051-9058.

Mendenhall, W. C. 1905. Geology of the central Copper River region, Alaska. U.S. Geol. Surv. Prof. Pap. 41.

Mercer, J.H. 1961. The response of fjord glaciers to changes in the firn limit. 7. Glaciol., 3(29), 850-858.

Miller, D.J. 1960. Giant waves in Lituya Bay, Alaska. U.S. Geol. Surv. Prof. Pap. 354-C.

Motyka, R. 1983. Increases and fluctuations in thermal activity at Mt. Wrangell, Alaska. (Ph.D. thesis, University of Alaska, Fairbanks.)

Muller, E. H. and H.W. Coulter. 1957. The Knife Creek glaciers of Katmai National Monument, Alaska. J. Glaciol., 3(22), 116-122.
National Research Council. Division of Earth Sciences. Committee on the Alaska Earthquake. 1968. The great Alaska earthquake of 1964. Hydrology. Part A. Washington, DC, National Academy of Sciences. (Publication 1603.)

Post, A. 1968. Effects on glaciers. In National Research Council. Division of Earth Sciences. Committee on the Alaska Earthquake. The great Alaska earthquake of 1964. Hydrology. Part A. Washington, DC, National Academy of Sciences, 266-308. (Publication 1603.)

Post, A. 1975. Preliminary hydrographic and historic terminal changes of Columbia Glacier, Alaska. U.S. Geol. Surv. Hydrol. Invest. Atlas 559.

Ragle, R. H., J. E. Sater and W. O. Field. 1965. Effects of the 1964 Alaskan earthquake on glaciers and related features. Arct. Inst. North Am. Res. Pap. 32.

Raymond, C.F. and W.D. Harrison. 1988. Evolution of Variegated Glacier, Alaska, U.S.A., prior to its surge. $\mathcal{J}$. Glaciol., 34(117), 154-169.

Reid, J.R. 1969. Effects of a debris slide on "Sioux Glacier", south-central Alaska. J. Glaciol., 8(54), 353367.

Shreve, R. L. 1966. Sherman landslide, Alaska. Science, 154(3757), 1639-1643.

Sturm, M. 1983. Comparison of glacier flow of two glacier systems on Mt. Wrangell, Alaska. (M.S. thesis, University of Alaska, Fairbanks.)

Sturm, M., C. S. Benson and P. MacKeith. 1986. Effects of the 1966-68 eruptions of Mount Redoubt on the flow of Drift Glacier, Alaska, U.S.A. J. Glaciol., 32(112), 355362.

Sturm, M., C. S. Benson and P. MacKeith. 1988. Recent glacier-volcano interactions on Mt. Redoubt, Alaska. Juneau, Alaska Department of Natural Resources. Division of Geological and Geophysical Surveys. (Report 88-9.)

Swithinbank, C. 1988. Satellite image atlas of glaciers of the world: Antarctica. U.S. Geol. Surv. Prof. Pap. 1386-B.

Tarr, R.S. and L. Martin. 1914. Alaskan glacier studies. Washington, DC, National Geographic Society.

Tuthill, S.J., W. O. Field and L. Clayton. 1968. Postearthquake studies at Sherman and Sheridan glaciers. In National Research Council. Division of Earth Sciences. Committee on the Alaska Earthquake. The great Alaska earthquake of 1964. Hydrology. Part A. Washington, DC, National Academy of Sciences, 318328. (Publication 1603.)

Viereck, L.A. 1968. Botanical dating of recent glacial activity in western North America. In Wright, H. E., Jr and W.H. Osburn, eds. Arctic and alpine environments. Vol. 10. Bloomington, IN, and London, Indiana University Press, 189-204.

Viereck, L. A. Unpublished. Report of the botanical work done during the 1957 expedition of the American Geographical Society as part of the IGY.

The accuracy of references in the text and in this list is the responsibility of the authors, to whom queries should be addressed. 